\title{
Homes of Crimes Social Stratification as Location Strategy in the Hungarian Family Crime Drama Aranyélet 'Golden Life'1
}

\author{
Péter MÉSZÁROS \\ Department of Communication and Media Studies \\ University of Debrecen \\ meszaros.peter@arts.unideb.hu \\ Dorottya MOLNÁR-KOVÁCS \\ Department of Communication and Media Studies \\ University of Debrecen \\ kovacs.dorottya@arts.unideb.hu
}

\begin{abstract}
HBO Hungary's original series, Aranyélet, proves to be an interesting case study in terms of location strategies in Eastern European TV shows. It is refreshing in the sense that - contrary to other TV programmes attempting to showcase life in Budapest - it does not feel the need to represent locality by swamping the viewer with iconic tourist destinations of the capital. Instead, the characteristic "Hungarianness" of the show appears through displaying personal living spaces of people from a wide range of socio-cultural backgrounds, all of which represent the typical Hungarian strata.

In our paper, we have used a simplified categorization of social classes apparent in Hungarian society and connected these groups with characters of Aranyélet. Then, we have scrutinized the living spaces of these characters as represented in the show, paying special attention to their likely location, furnishing, building materials, and general condition. By this analysis, we aim to prove that the show tries to create an alternative mental map of Budapest and its population, covering all strata of society with painting a picture of their lifestyle and living conditions.

Our paper draws on the work of Kim Toft Hansen and Anne Marit Waade, who, in their volume Locating Nordic Noir - From Beck to The Bridge, place a large emphasis on aspects of location studies in contemporary Scandinavian crime.
\end{abstract}

Keywords: quality television, series, social strata, living spaces, location strategy 


\section{Introduction}

Original content creation in the new aesthetics of "quality television" arrived rather late to Hungary, with HBO Hungary's first original series, Társas játék, airing in 2011, and HBO Central Europe having remained the most important production company in that regard ever since (Gardiola 2010). This new era of television consists of sophisticated, artistic content that frequently breaks conventions of creative practices, paired with well-thought-through branding strategies (Thompson 1996: 13-16, McKabe-Akass 2008: 83-93). Quality TV content has been introduced to Hungarian audiences in the early 2000s, around the time Sex and the City premiered on HBO channel in 2002, but original, Hungarian shows in line with the new expectations are still fairly recent phenomena in local television culture.

Aranyélet - or Golden Life in English - is worthy of the media researcher's attention for a couple of different reasons: besides being one of the first representatives of quality television in the country and a flagship project of HBO Hungary, it was also an instant success with the public. Critical acclaim has not been scarce either; Aranyélet was quickly named "the greatest Hungarian television show of all time". ${ }^{2}$ After the Hungarian debut, it was soon released in several European countries either on HBO channel or on HBO Go. In 2018, it was also released in the United States, which is a rare achievement for any Hungarian production.

Although the show is loosely based on the Finnish original, the plot and character developments differ greatly right from the second episode to make it reflect closely on local social issues and character archetypes. ${ }^{3}$ The creators' intent for the show to talk specifically about Hungary is clearly visible in the types of petty crimes often represented in the plot or the general presence of corruption and fraud in everyday life. Character types, everyday objects and symbols of social and cultural class - such as homes and cars - also play an important role in telling stories and painting a picture of the Hungarian society as a whole.

In our paper, we aim to provide a visual overview of the home environments presented in Aranyélet, keeping in mind that more often than not these spaces are crime locations or spaces where crime is organized. What we see are typical living spaces of Budapest put in a new context: homes are either a "reward" of

the authors' views, and the Agency and the Commission are not responsible for any use that may be made of the information it contains.

2 In a 2015 critique, IGN Hungary wrote: "Aranyélet is not only one of the best Hungarian shows ever made but one of HBO's best thrillers as well” (https://hu.ign.com/aranyelet-1-evad-7-es-8resz/9621/review/kritika-aranyelet-1-evad-7-8-resz-finale). Player.hu writes it is the best thing that could have happened to Hungarian television (https://player.hu/kult/aranyelet-3-evadkritika/), while Nlcafe.hu claims the following in an article title: "The best Hungarian TV show of all time has been born" (https://www.nlcafe.hu/szabadido/20151109/aranyelet-kritika-onodieszter/).

3 The original Finnish version, Helppo elämä, by MTV3 was first aired on 5 January 2009. 
crime, an indication of success achieved by not abiding by the law, or the reason for committing crimes - the only way out of a hopeless situation. An important subject of the show is social mobility that is usually achieved - or is seemingly only achievable - by breaking the law. This means that living spaces along with their furnishing and other personal objects connected to it - such as cars - are important indicators of the current state in climbing up the social, economic, and even cultural ladder of their owner.

Our research is largely inspired by Kim Toft Hansen and Anne Marit Waade's studies on Nordic Noir as they view Scandinavian crime fiction in the context of "the spatial turn in media studies" - a phrase coined by Jasper Falkheimer and André Jansson in 2006, which indicates a higher level of focus aimed at space and place in analysing media texts (Falkheimer-Jansson 2006). In the new interdisciplinary field that has emerged due to this increased attention on location in media texts, phrases such as "geography of communication" (FalkheimerJansson 2006), "cinematic geography" (Roberts 2012) and "mediaspace" (Couldry-McCarthy 2004) became part of the discourse (Hansen-Waade: 12). In the Introduction of the book, they write:

'Instead of asking “what is Nordic Noir?”, which in itself is a very difficult question to answer, this book asks "where is Nordic Noir?". This enables us to pinpoint a conspicuously spatial modus operandi, a topography, in the accentuation of place in Nordic Noir and, perhaps, in TV drama in general. (Hansen-Waade: 10)

Nordic noir is an especially adequate phrase to label their work as the subgenre has become a recognizable transnational brand in the past few years (HansenWaade: 4-9). In the work of the Danish authors, central focus is directed at locality, geographical landscape, and the society and culture where the crime narrative is set (Hansen-Waade: 9-13, 53-76).

Where Hungarian crime fiction is located in terms of physical location as well as socio-cultural setting is an equally valid and interesting question, especially when studying a media text made for international as well as local audiences.

The Danish authors recommended to us Serra Tinic's ("place-as-character") (Tinic 2015), Todd Soldano's (“city as character") (Soldano 2015), and Lynn Spigel's ("TV places”) (Spigel 2005) concepts (Hansen-Waade: 11-33). All of these concepts reflect on identifiable space representations, where interaction between real and diegetic spaces can play an important part in location strategies and the in-placement of "local colour". British geographer Tim Edensor groups the spatial structures that appear in popular media texts for localization purposes (Edensor 2002). "The six different spatial categories that deal with national identity and imageries are listed as: (a) ideological rural national landscapes, 
(b) iconic sites, (c) sites of popular culture and assembly, (d) familiar, quotidian landscapes, (e) dwellingscapes, and (f) homely spaces" (Hansen-Waade: 42).

Based on the observations of Péter Mészáros (2016), the space management in earlier series of HBO Hungary is overlapping with the phenomenon described in the cited literature. Nonetheless, there are clear differences in the use of space between these earlier texts and Aranyélet. The show does not feel the need to represent locality by swamping the viewer with iconic tourist destinations of the capital. However, the last of Edensor's groups, "homely spaces", feels overrepresented. Hansen and Waade show us in Nordic noir that homely spaces can represent local colour as ionization of Nordic design and architecture (Hansen-Waade 2017: 78-81) or reflecting the mental state, mood, or emotions of the protagonist (Hansen-Waade: 127-144). The seemingly large number of home representations in Aranyélet drew our attention to addressing this topic further.

Our hypothesis is that the Hungarian HBO show Aranyélet displays spaces belonging to people of a wide range of socioeconomic and cultural backgrounds. It is almost as if the show has taken it upon itself to represent the classes and demographic groups that the Hungarian nation, or more specifically, the population of Budapest, the show's main hub consists of. We aim to prove our hypothesis by a simple content analysis which lists all the home spaces in the text of the series and categorizes the character in that space into a hypothetical demographic group based on the character's story. We understand that this might not have been the creative intent behind choosing and arranging filming locations, but this study solely focuses on what we see on the screen. Because of the methodologies used in this paper - all of them connected to media text analysis rather than data collection from the show makers -, we are unable to take into consideration the possible goals in mind that could have contributed to the location strategies of the series. In the future, however, we are planning to interview HBO creators on the subject of Aranyélet

\section{Demographic overview of the Hungarian society - The "Hungarian pear"}

It is the in the nature of all sociological accounts that they can only be partial. Even so, social stratification has long been a crucial point of sociology because it helps us understand and ultimately deal with inequality, thus making this area an important tool in the hands of (mainly leftist) political aspirations.

When analysing Aranyélet's representation of social classes, we refer to Karl Marx's ideas on class, where a person's role in society depends mainly on economic conditions. When discussing class identity, however, we rely on Max Weber's concept of class, where it is much more the product of someone's education, 
intellectual accomplishments, and cultural taste, thus class being something to be gained (Waters-Waters 2015: 2-17, Benshoff-Griffin 2009, Hess 2001).

According to the biggest Hungarian study of social classes so far, a complex survey conducted by GfK Market Research and the Hungarian Academy of Sciences in 2014, the Hungarian demographic map looks a lot like a pear. ${ }^{4}$ The upper and upper middle classes are very thin, and most of the population is in the lower middle classes, the underclass being the largest group of all with $23 \%$ of the population (Kozák-Veres 2014: 24-25).

The basis of the survey was Bourdieu's capital theory, studying the effect of the possession of economic, social, and cultural capital on the social stratification of a country (Bourdieu 2004).

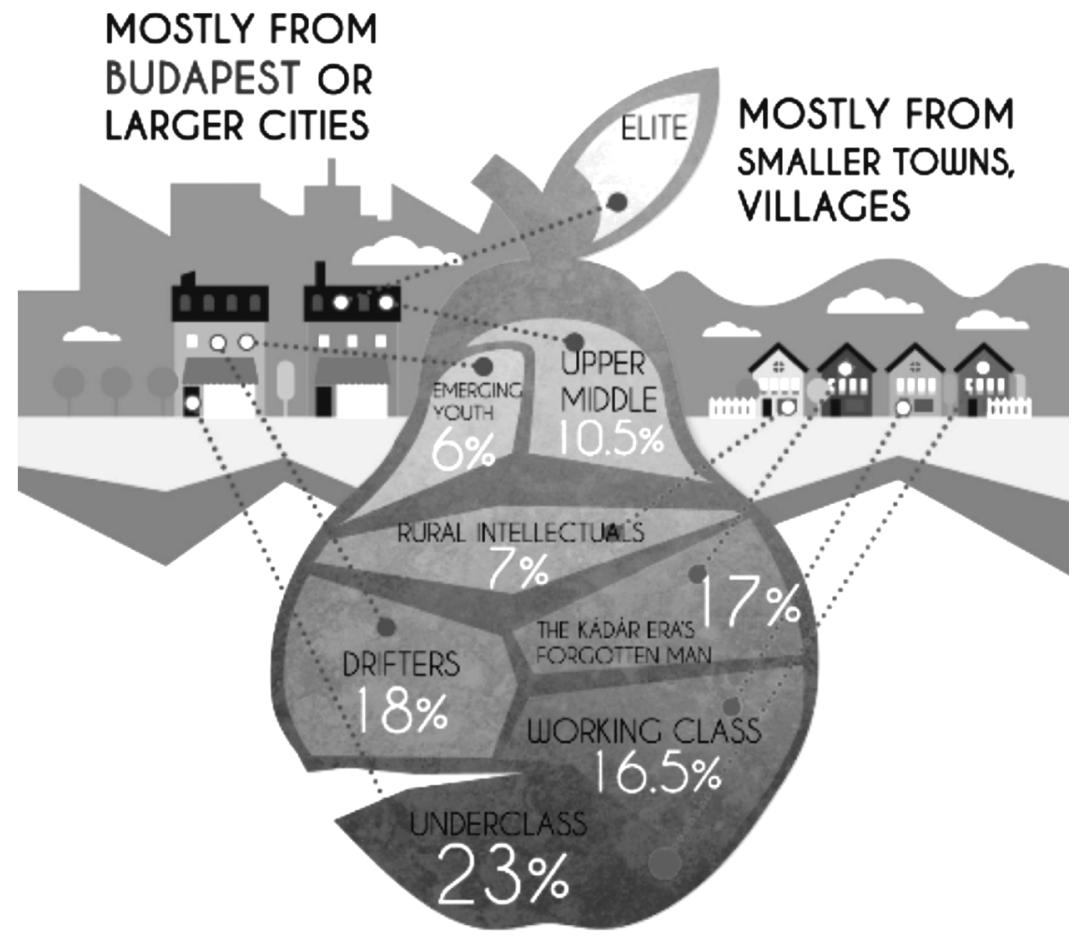

Source: GfK-MTA Osztálylétszám 2014

Figure 1. The "Hungarian pear": the structure of the Hungarian society

$4 \quad 13,560$ people have participated in the study titled Osztálylétszám. The Structure of Hungarian Society. The study has adapted the BBC's The Great British Class Survey method to domestic conditions in order to define and measure classes of the Hungarian society, taking into account economic, relationship, and cultural capital available to the individual. 
Although using social classes to characterize a society can be viewed as an outdated and an overly simplifying practice among scholars, in this study, we have been careful not to refer to classes as existing and fixed categories but rather as a set of cultural characteristics paired with economic standing.

The never before seen scale of the abovementioned Hungarian social stratification study has provided a unique look into the layers of the Hungarian population. Moreover, the large media attention it received in 2014 suggests that the survey significantly contributed to the revitalization and renewal of studying classes in social sciences (Banóczi-Kabai-Kovássy 2015: 130).

According to the results of the mentioned study, despite expectations, a strong middle class has failed to develop in Hungary after the regime change. Surprisingly though, a significant upper middle class is visible, suggesting that both ends of the spectrum are populous. In this system, however, working class is not divided into further subgroups, and urban intellectuals seem to be missing from the table. An analysis of the results suggests that mobility between classes is very limited: sliding down the social ladder is relatively easy, while climbing up on it is hard.

As visible on the chart, there is a significant difference between rural and urban life in Hungary, a fact that could be simplified by saying: the difference between life in Budapest and the rest of the country is substantial.

Hansen and Waade cite a study conducted in Wales that can be of interest in this context: Ruth McElroy researched how television drama series produced in Wales, such as Hinterland (2013-), Doctor Who (2005-), and Sherlock (2010-), play a role in branding the nation and also give an opportunity for audiences to relate to the locations displayed in the series. This is relevant not only in terms of destination tourism but also in media communications: screening nations or regions as such includes implications on "the representation of places, the political and economic conditions for the influence of places on culture and media production, and, finally, the commodification of places in global market cultures" (Hansen-Waade: 54).

To study the economic implications of each setting in Aranyélet, it is important to identify characters and their implied social statuses.

Most of the 8 social classes identified in the study are represented in one way or another in Aranyélet. From the wealthy billionaire through the influential politician to the struggling working class, characters of Aranyélet undoubtedly represent varied groups of the Hungarian society.

The main characters, the Miklósis, are a "new money" family who already possess the wealth to be part of the upper middle class but lack the high education and social status usually associated with this class. The Hungarian upper class members are normally from Budapest or a larger city, have a wide social circle, lots of free time, which they spend wholesomely, consuming high-brow culture 
and leading an active lifestyle. Although the Miklósi family barely fit even in this categorization, they are aiming to be in the upper $2 \%$, in the élite. Throughout the show, they are actively trying to establish relations with this very closed social group and are trying to increase their wealth to their level. With the Miklósi family, this involves lots of "faking it" and systematic violations of the law.

Politicians and high-level criminals of the show represent the thin layer of the élite of the Hungarian society. They have already established the social relations as well as the economic condition associated with this group. Characters such as Ferenc Gáll, Endre Hollós, Kálmán Csér, or Zsuzsa Boros, are powerful individuals not afraid to transgress the law. They are corrupt and have strong bonds with noted criminals. It seems like the Hungarian drama finds it unlikely for ethical, law-abiding élite groups to exist. The Hungarian élite is only $2 \%$ of the society, 200 thousand people at most. They are usually descendants of the same group, and their status is virtually hereditary.

Some $6 \%$, half a million people are in the group the study calls emerging youth, a layer of young or middle-aged individuals who have the skills and relationships - in essence, the potential - to move up the ladder. In Aranyélet, we see a young generation who, even though might possess the potential to become whatever they want to become, usually fails to do so, and they turn to crime instead. Márk Miklósi, one of the young protagonists of the show, is first trying to make it as a musician, then as a car thief, a petty criminal as well as an infamous criminal by the end. As a thriller and a crime drama, Aranyélet does not give examples of fulfilling promising destinies.

Rural intellectuals make up $7 \%$ of the Hungarian population: teachers, doctors, and local public figures of smaller towns and villages. They rarely appear in the show, set mainly in the capital. In the third season, when the setting moves to Börzsöny, a fictional town close to the capital, Barbara Nyíredi, a journalist, who is the "moral compass" of the storyline for a while, represents the group. Detectives and lawyers portray the urban intellectual group of the show.

Forgotten people of the Kádár era make up a larger, one and a half million group of the population. They are the average Joes struggling, essentially making it day by day. This rural group is largely left out of the series.

Drifters are the other group of the population, made up of young people who lack the family background, education, wealth, and social status to succeed. In a sense, Miklósi Márk's peers and partners in crime could be considered drifters.

The study shows that $16.6 \%$ of the population is working class, while the remaining $23 \%$ is underclass. Oszi, a young Roma girl ending up in prostitution is one representation of the latter, while Janka Miklósi's long forgotten family living on agriculture in a small farm is of the former one. If the family had not been caught up in illegal businesses, they would most likely be part of the working class. 
By the last episode, we see an overly idealized, romantic picture of a "workingclass" Miklósi family, where the ex-criminals find happiness and fulfilment by the simplest life imaginable. The only member of the family with a relative improvement of social status, the daughter, Mira Miklósi, who is beginning her career as a detective, is still a member of the working class by Hungarian standards.

\section{Analysis of living spaces portrayed in Aranyélet}

Taking into consideration that "places can 'play a role' in TV drama almost in the same way as an actor or actress plays a part", analysing the settings of Aranyélet proposes the question of the role each setting is intended to play in the viewer's mind. Although using actual, real-life places for filming locations is nothing new under the sun, McHale and Booker emphasize a current trend in TV fiction in which there is a constant blurring of the boundary between the fictionalized locations and the real-world places - a tendency often regarded as an indication of a postmodern mind frame (McHale 1987, 32; Booker 2007).

In this paper, however, we do not analyse public places represented in the series that could blur lines between fictional and real-life locations. Instead, we focus on the fictionalized home environments that are supposed to represent - at least in our view - ways in which different strata of the Hungarian society live.

Of course, the level of representation differs from real social proportions, but we have found twenty different homes covering a number of different social strata in the text. These are twenty homes of major or minor characters displayed in the 30 episodes - one hour each - of the three seasons. This number is rather high considering that most of the show takes place in and around the homes of the main characters and in public places.

Looking at their involvement in crime, it is worth noting that only two families are innocent in all respects. This makes Aranyélet seem a lot like a sociographical crime journey. Sometimes the homes are the crime scenes - not an unusual thing in this genre-, but most of the time crimes take place in public or abandoned places. In this paper's interpretation, real estates and social status in Aranyélet are more often results of or rewards for crime rather than simply scenes of lawbreaking. Since the study focuses primarily on homes, we do not take into account whether the characters talked about play a protagonist or more of an antagonist role in the series. The show lacks characters that have a lasting simplified moral compass role. Moral heroes of Aranyélet often turn out to be lawbreakers. With all this in mind, our investigation focuses only on the social status of the owner of the home and the crimes he or she has committed.

Our method is to connect the homes of Aranyélet with the strata of the Hungarian society according to the abovementioned study conducted by GfK 
Market Research and the Hungarian Academy of Sciences (Kozák-Veres 2014: 24-25). This paper focuses on how the show is representing these strata and connects the homes with the crime committed by the character they belong to.

\subsection{The Élite}

Most scenes take place in the vicinity of the élite, where the Miklósis want to belong. Crime is part of the everyday life for a character who belongs to this class. The élite is quite diverse in the show. One of their main representatives is Endre Hollós. Hollós is an important character, who is connected to most members of the Miklósi family by strong bonds: best friend of the father, Attila; lover of the mother, Janka; and godfather for the son, Márk. Hollós was a drifter during and before the regime change, built an empire on sin, and became a high-level figure of the organized crime life of Budapest.

His home represents the drifter roots and an upstart taste. The classicizing villa is full of large spaces and expensive materials such as marble, leather, and hardwood. The swimming pool, the bar, and the study, packed with bookshelves are all in central position even though we never see him reading, and on one occasion he openly questions the usefulness of knowledge from books.

There are multiple bedrooms in his residence although he lives there alone in the first episode, when we get to know the character. Throughout the episodes, his home is mostly for representation rather than to serve as a comfortable home, and the most featured scenes are the gate, the driveway, and the entry hall. Hollós owns a poker table for holding regular gatherings for his business partners. Although the garden is also suitable for holding events like these, only the next owners of the residence will use it for a garden party. Another function of the villa is keeping secrets and hiding various objects. This function is mostly connected to the kennel, where his two beloved bloodhounds live. The villa is deeply connected to crime in all aspects.

Another villa owner is Kálmán Csér, lover of the Miklósi mother, Janka, and a rich CEO. Csér was an emerging young economist. He "only" commits whitecollar crimes such as tax evasion, embezzlement, and fraud. An indication of his sketchy businesses is that all of his luxury cars have a Slovakian licence plate completed with a fake disability certificate used for free parking.

Classicizing, new-money taste that was so obviously visible in Hollós's house is nowhere to be seen in Csér's villa. His home is full of high-tech gadgets and expensive, modern materials, such as glass or metal, and timeless classics such as leather and hardwood. In addition, it is a minimalist architectural masterpiece. Design seems to be more important for him than for Hollós, but even so his home is not a place of representation. There is no garden, and the living room and terrace with the pool are both too small for social gatherings. There is no study 
as far as we can see: the whole residence is built for personal relaxation and recreation.

The difference between the two homes can be related to the different backgrounds of the characters: a former drifter and an emerged - former - young intellectual. Both homes meet the basic needs of their owners and, in addition, provide extra luxuries depending on their lifestyles. Common features in both homes are spacious rooms - even if they are not always fit for parties - filled with expensive materials, and a comfortable distance and distinct fencing separating the property from the neighbours.

There are two more buildings in Aranyélet which represent the same stratum and that belong to minor characters of the show. One is a villa of a corrupt state secretary, and the other is the house of a building contractor, who is consistently overpricing work for her wife's foundation. We could argue, however, that the latter family is part of the upper middle class and not of the élite.

It is hard to say whether the home of the Miklósi family in Season 3 is a representation of an élite residence or not. By this point, the family has sunk quite deep in sin but are quickly rising on the social ladder. The Miklósi Villa in Season 3 is not in Budapest, and we know that it was previously owned by a gangster. In its appearance and size, it follows the patterns of the Hollós Villa, while mimicking a rural, Mediterranean style.

The rural mansion of Feri Gáll - who plays a sort of a "godfather" character in the show in every sense of the word - lies somewhat outside of the spectrum of this study as it is not situated in Budapest. It is, however, worth a mention as it portrays a fundamentally different aesthetics than the abovementioned ones. Gáll's two-storey chateau is an example of vernacular architecture with its simplistic, folksy exterior and impressive, open-plan interior. The furnishing of the living room - which is the space we see the most - highlights the differences between a new-money Budapest lifestyle and a classy, comfortable rural living. Natural materials such as leather and wood dominate the space, which is filled with books - reinforcing the feeling of slow, village living but also giving an intellectual vibe to the home of a character who is essentially the brains behind elaborate criminal activities.

\subsection{Upper middle class}

The most important motivation of the protagonist family is to advance on the social ladder. In the first episode of the series, we meet a family living in a suburban area of Buda. In the neighbourhood, upper-class families live in detached houses with spacious gardens. In their two-story house, the Miklósi parents and the two children all have their own rooms, a garage fit for two vehicles, and a sauna. The house is a modern minimalist building with the interior reflecting a carefully 
designed and deliberate architectural concept: angular shapes, whites and greys dominating on walls, in furniture, even in decorations. Apart from the children's rooms, the interior looks as if chosen from a catalogue - much to the contrast of the average lower-middle-class Hungarian family homes, which are usually designed and decorated haphazardly, resulting in a homely but not exceptionally aesthetic environment. The Miklósi house is a symbol of easy life accessible by sin, and it is on the border of élite and upper middle class.

The neighbouring house of Klára and Ambrus is similar in style and appearance. The difference between the two families occupying these homes is stark: while Klára is involved in the work of a homeless care foundation, Janka is trying to use the organization for her own social advancement. We do not know about the professions of the residents in the area, but Klára and Ambrus are among the few characters in the series without represented crime. Despite the fact that there are multiple scenes filmed in or around their house, it still looks quite blank and minimalistic in decoration. We see the white, simply furnished living room from an inner angle, with the terrace separated only by a large glass wall in the background. We can see Ambrus smoking on the balcony, we see them gardening, and the viewer also learns that their first car was a Škoda during the time of the socialist regime - Klára remembers this with nostalgia. But there are no objects indicating their identity and virtually no colours around them. By watching them from the point of view of the protagonist family - which is identical to the viewpoint of people watching the show -, we assume them to be an educated, self-made, upper-class couple.

Another character from the homeless care foundation is Judit - also mentioned in the élite context. She also has a pool on her property, but her garden is smaller. She lives in a densely populated area in comparison to the élite.

Beyond basic function, all of these homes have spacious living spaces suitable for receiving guests. The rooms are usually bright, roomy, and tastefully decorated. The geographic features of the area - visible hills - suggest that these homes are most likely in Buda, the western part of the city, which is an area known to be populated by people from higher levels of society.

\subsection{Emerging youth and drifters - The young generations}

The 2014 study on the Hungarian social structure mentions two groups that consist mainly of the younger (or at least middle-aged) generation. Young people who get a head start in life through their family and educational background are the emerging youth - virtually the only group in this categorization with a good chance for upward social mobility. Their peers without that head start, having no relationships and having received a poor education are likely to become drifters: wondering through life without stability, changing jobs frequently, and lacking a promising vision for the future. 
The younger characters of Aranyélet cannot be easily put in either one of these categories. If we take a look at the apartment of the Student Body President character, we see a messy rented flat full of entertainment devices. The living environment suggests occupants ready to use the weaknesses of the system for their own advantages. The young opportunists, trained in university politics, represent a future generation of immoral and corrupt politicians, armed with a valuable social network and the ability to embezzle funds and move up the social ladder - maybe even as far as the élite.

The convicted felon, Pisti Mátyás, who is a Roma father in his thirties or early forties, represents another group of Hungarian (relative) youth. He is a drifter in the sense that we are unaware of any occupational qualifications of his; he is most likely a contingent worker, supporting his family by constantly breaking the law. Based on the spacious, two-story suburban family home he has built, he is moderately successful in his affairs. However, he has no intention of leaving "his people" and moving out of the poor quarter with a significant Roma population. Rather, he becomes a gipsy gang leader with his large, architecturally unimpressive house looking like a palace among the humble wooden huts and tiny, worn-down cabins along the dirt roads.

Looking at the interior, we see indicators of Roma identity - garish colours and traditional decoration - combined with Catholic religious symbols.

\subsection{Rural and urban intellectuals}

The archetypical homes of rural intellectuals in the show are represented by the wooden house of Barbara Nyíredi, the journalist. The house is in Börzsöny, outside of the city. In this paper, we focus on homes situated in the capital because outside the city the sample is too small for proper comparison. Even so, the house of Barbara is definitely worth a mention. Her little garden in front of the building is well kept up, thoughtfully arranged, and full of flowers. The home is also neat, with natural colours and a combination of rustic and modern design. Barbara is the moral compass of the show during her journalist career, but she eventually gives up the fight and becomes a spokesperson for corrupt politicians.

In the case of urban residents that are closest to this stratum, we found it difficult to categorize some of the homes represented in the show, using the classes provided by the 2014 study of the Hungarian society. These characters all have intellectual jobs, and their homes are definitely comparable to each other, but the lifestyle of the characters hardly match the upper-middle-class samples from the show - the only group that is close to the rural intellectual stratum but is suitable for residents of Budapest that the survey has identified. For this reason, we have decided to use the category of urban intellectuals instead to talk 
about intellectuals living in the capital as well - a group that we would otherwise identify as middle class in the broad sense of the term.

Rural or urban intellectual characters are guilty of petty crimes at most. One of them is Géza Zebegényi, a divorced state attorney, whose flat in a renovated block of flats becomes an important place in the show, and it is ultimately the home of the Miklósi girl, Mira. However, in the beginning of her relationship with the forty-three-year-old man, she is practically an adolescent. Another crime of Zebegényi is that he is not afraid of the unlawful collection of evidence which, however unlawful, is potentially morally superior to not trying to get to the bottom of cases.

His lifestyle and the objects of his house suggest his belonging to the middle class: his apartment is full of IKEA furniture, and he owns a large number of books. His kitchen is modern, but the bathroom is too small to make the shootings, so it is not filmed at all. We can interpret his living conditions in the block of flats as a result of committing crimes that do not bring material goods. Therefore, although his "crimes" might be justifiable in some sense, they are not rewarded by money either, and committing them is essentially pointless if the goal is personal success.

Another example in this stratum is the apartment of detective Erika Jakab in Buda. Her apartment is certainly of the same social class as Zebegényi's flat. The style is different, but similar markers can be noticed: IKEA furniture, modern, probably mass-produced decorations, and a decent-sized living area. Although likely, it is not completely clear whether she gets money for being an undercover agent of an oligarch in the police because her motivation of crime is first and foremost vengeance as opposed to economic well-being. The homes of the detective and the attorney are both worked out to the last detail.

Another home of an urban intellectual is from an outer district, a newly built area of the middle class. The owner, Imre Strasszer, is a corrupt bank employee. The outside of his attached home is beautiful; it is one of at least thirty of the same kind of terraced houses on the street. The inside, however, is crowded, and the design is eclectic. There seems to be no sign of civic identity in the interior.

In a different part of the city, at a modern housing estate, we see two more middle-class apartments, belonging to victims rather than criminals. In the first season, Attila, the father, breaks into apartments and impersonates a real estate agent showing the apartments as open houses. If someone decides to rent the flat, Attila disappears with the deposit. Through these examples, we can see ideal living spaces of young couples and individuals trying to find their first - rented - apartment. In the diegetic world of the series, they are not innocent: Attila's scam can only work because tenants are not afraid of tax evasion, writing an improper or incomplete contract in order to pay less rent. We could argue that the abovementioned young renters in the first season are also members of the working class, but the truth is that we do not get much information about their background. 


\subsection{Forgotten people of the Kádár era}

This stratum is clearly less represented in the show than the ones mentioned above. However, one example is worth talking about: the house of the retired colonel, Mihály Miklósi, and his wife: the parents of Attila. Although he is not typically a member of this class - his economic and social status from being a former colonel is clearly way too high to be considered a forgotten man -, his home bears some attributes associated with this stratum. However, the furnishing reminds us of the environment of the average Joes of the Kádár era: a generation who could prosper during this period only by constantly stealing from their workplace - a common practice during those years among the working class. The communist colonel used to smuggle art through the border during the socialist regime. His reward was the impressive, civic house in the capital, which was obviously beyond their means. Many years have passed since the regime change, but in the house time has stopped, and the furniture is still the same. It has been a long time since the building was renovated, and it seems like the residents could only conserve the building but without any realistic chance of improvement.

A number of scenes play a special dramaturgical role in this house: in the second season, there are two parallel timelines. One is a flashback to around 20 years ago, when we see a young Miklósi couple in the parents' house. The other is the diegetic present of the show. The Miklósi family had to move back to the house, evoking a sense of past in the viewer as well as in the characters' mind.

\subsection{Working class}

In comparison to other strata, there are only a few cases of the working class appearing in the series. A clear example of the group, however, is the home of Zoli and Hanna, a small business owner couple living above their self-operated ruin pub in an old civic apartment in the party area of Budapest. The furniture is upcycled and refurbished, and the design is eclectic, just like in the pub right under their flat. In most of the scenes they appear in, we see them engaged in crime: both of them - even the pregnant mother - are marijuana smokers, they dilute the drinks they sell with water, and at one point the man tries to seduce young Mira Miklósi.

Earlier in this paper, we have mentioned that based on their qualifications and background the Miklósi family would have likely belonged to the working class without crime or at least to the group of the Kádár era's forgotten people. The typical home belonging to this class in an urban block of flats, however, only appears at the end of the last season. The series puts the story of the characters in a stagnant yet idyllically depicted, small bourgeois, working-class life in a block of flats. In our interpretation, the story also implicitly claims that starting out 
from the lower classes of society this is the highest social level that members of Hungarian society can reach without crime.

\subsection{Underclass}

The Budapest underclass is traditionally imagined living in run-down, crowded blocks of flats built in the Soviet era in the style of socialist realism. These buildings are famously unfit for comfortable living. They were built with one purpose in mind: to house as many occupants in just a few square meters as possible - no matter the cost. The social life in these buildings mainly takes place on the common porch areas along the corridors.

A Gipsy girl, called Oszi - who ends up in foreign prostitution and even becomes a victim of trafficking for a short while -, lives in a flat like this with her family at the beginning of the series. The area is most likely the Havanna blocks, one of the most infamous neighbourhoods of Budapest, with a very dense population and an even higher crime rate. Oszi does not have her own bedroom: the flat is crowded and furnished with old, weary pieces from the socialist era. The family not having enough room in the flat is not a surprising situation: flats are supposed to be "starting homes" from where young couples can move up in a few years, maybe even to their own house. This familiar fantasy, however, remains a fantasy for most people of the underclass.

Even though this is a violent environment with a drug addict and a lack of personal space around her, Oszi is trying to live a decent life. As she attempts to help Mira, the Miklósi daughter, she loses her job, forcing her to move to Switzerland as a prostitute. This unfortunate event becomes her chance to move up the social ladder: moving back home to Budapest, she can afford her own residence, now in a civic apartment building in the city. This is a significant progress in Oszi's living conditions. It is likely that the apartment is still in the notorious $8^{\text {th }}$ district of Budapest, and it is quite old and needs a renovation, but at least she now lives on her own with brick walls rather than concrete panels surrounding her. The interior is simplistic, we could even call it empty; it is not overly decorated, but it does have a woman's touch on it, and it serves as a safe haven for the young lady with such a difficult history. It is telling that the two Roma characters in the show both do well considering their starting situations, yet they both decide to stay in their familiar surroundings and not to move out and away from their familiar communities. 


\section{Conclusions}

The main goal of this paper was to investigate the kind of society HBO's Aranyélet represents relative to the actual structure of the Hungarian society. To do this, we have scrutinized the living spaces of characters from very different statuses, as represented in the show, paying special attention to the suggested location of the homes, to the general condition, style, and furnishing of the spaces, and the lifestyle their layout suggests. For a much deeper analysis, we could have compared just the kitchens - or living rooms per se - of an elite home to a working-class home, down to the very last tile and decorative item, and this is something we would find to be an interesting continuation of this study in the future. The present paper, however, only tries to present a general overview of all the main private locations the series showcases, with the aim to prove that the social structure presented by HBO's hit series provides a rather accurate interpretation of the lifestyle of the different stratum of the Hungarian society.

The series Aranyélet - and productions of the Eastern European HBO in general - provides a number of examples where localization, re-positioned and re-branded spaces become the main focal point in the text of the TV series. During our research, however, we have realized that the mediascape represented in the series contains magnifications, or zoom-ins, into living spaces that represent and typify the personal spaces of social classes in a fairly wide range.

As part of a larger, international research on crime fiction (including locality), this paper only tries to prove that hypothesis with the close reading analysis of the texts themselves. In doing so, we have identified all the living spaces represented in the media text, after which we have connected them to relevant social classes. We have also included how crime in narrative crime fiction relates to the social classes represented. We have concluded that the hypothetic wide spectrum is actually a full spectrum based on a recent sociographical systematization.

The analysis of home environments in Aranyélet will be the first part of a larger study first aiming to examine the location strategies of the series including the use of public spaces. That then will be incorporated into an even larger study aiming to characterize location strategies in contemporary European crime genres. 


\section{References}

Aranyélet Kibeszélő Második Évad - 1. rész - Vendég: Farkas Franciska. 24.hu YouTube channel. https://www.youtube.com/watch?v=BLYrQgraKxY (downloaded on: 19 May 2019).

Banóczi, E.-Kabai I-Kovássy K. 2015. A „körte”. Jel-Kép 2015/3: 121-144.

Benshoff, Harry M.-Sean Griffin. 2009. America on film: Representing race, class, gender, and sexuality at the movies. Malden, MA: Blackwell.

Booker, Keith. 2007. Postmodern Hollywood: What's new in film and why it makes us feel so strange. Wesport: Praeger.

Bourdieu, Pierre 2004 [1983]. Gazdasági tôke, kulturális tőke, társadalmi tőke. In: Angelusz R. (ed.), A társadalmi rétegzôdés komponensei. Budapest: Új Mandátum Könyvkiadó. 122-136.

Couldry, Nick-Anna McCarthy (eds). 2004. MediaSpace: Place, scale, and culture in a media age. London: Routledge.

Edensor, Tim. 2002. National identity, popular culture and everyday life. Oxford: Berg Publishers.

Falkheimer, Jesper-André Jansson (eds). 2006. Geographies of communication: The spatial turn in media studies. Göteborg: Nordicom.

Feltey, Kathryn-Sutherland, Jean-Anne (eds). 2013. Cinematic sociology. Thousand Oaks, CA: Sage.

Gardiola, C. 2010. HBO Central Europe adapts Israeli show. Shalom life. https://web.archive.org/web/20131104192043/http://www.shalomlife.com/ culture/12619/hbo-central-europe-adapts-israeli-show/\# (downloaded on: 17 May 2019).

Hansen, Kim Toft-Waade, Anne Marit. 2017. Locating Nordic noir. From Beck to The bridge. Palgrave Macmillan.

Hess, Andreas. 2001. Concepts of social stratification. European and American models. New York: Palgrave. 10-36.

Kozák, Á.-Veres, E. 2014. Társadalom és rétegződés. In: Hetesi E.-Révész B. (eds), „Marketing megújulás”. Marketing Oktatók Klubja 20. Konferenciája elóadásai. Szeged: Szegedi Tudományegyetem, Gazdaságtudományi Kar. 16-27.

McHale, Brian. 1987. Postmodernist fiction. New York: Routledge.

McKabe, J.-Akass, K. 2008. It's not TV, it's HBO's original programming. Producing quality TV. In: Leverette, M.-Ott B. L. (eds), It's not TV: Watching HBO in the post-television era. Buckley, C. L. 83-93.

Mészáros, Péter. 2016. Transzmediális történetmesélés és a földrajzi tér szerepe az HBO Magyarország adaptált sorozataiban. In ME.DOK 11(2): 53-62.

Roberts, Les. 2012. Film, mobility and urban space-A cinematic geography of Liverpool. Lancaster: Liverpool University Press. 
Sodano, Todd. 2015. It was TV: Teaching HBO's The wire as a television series. In: Karen Dillon-Naomi Crummey (eds), The wire in the college classroom: Pedagogical approaches in the humanities. Jefferson: McFarland. 7-31.

Spigel, Lynn. 2005. Our TV heritage: Television, the archive, and the reasons for preservation. In: Janet Wasko (ed.), A companion to television. Oxford: Blackwell Publishing. 67-99.

Thompson, R. J. 1996. Television's second golden age: From Hill Street blues to ER. New York: Continuum.

Tinic, Serra. 2015. On location: Canada's television industry in a global market. Toronto: Toronto University Press.

Waters, Tony-Waters, Dagmar. 2015. Max Weber's sociology in the twenty-first century. In: Waters, Tony-Waters, Dagmar (eds), Weber's rationalism and modern society. 2-17. 